\title{
INFLUENCE OF PIERS ON FUNCTIONAL GROUPS OF BENTHIC PRIMARY PRODUCERS AND CONSUMERS IN THE CHANNEL OF A SUBTROPICAL COASTAL LAGOON
}

\author{
Paulo Roberto Pagliosa ${ }^{1 *}$, Mauricio Cantor ${ }^{l}$, Fernando Scherner ${ }^{2}$, Mariana Beatriz Paz Otegui ${ }^{l}$, \\ Aurea Luiza Lemes-Silva ${ }^{1}$, Cintia Dalcuche Leal Martins ${ }^{I}$, Giorgia Freitas Alves ${ }^{1}$, \\ Alessandra Fonseca ${ }^{2}$ and Paulo Antunes Horta $\mathrm{Jr}^{1,2}$ \\ ${ }^{1}$ Universidade Federal de Santa Catarina \\ Programa de Pós-graduação em Ecologia \\ (Cep. 88040-900 Florianópolis, SC, Brasil) \\ ${ }^{2}$ Universidade Federal de Santa Catarina \\ Programa de Pós-graduação em Biologia Vegetal \\ (Cep. 88040-900 Florianópolis, SC, Brasil) \\ *Corresponding author: paulo.pagliosa@ufsc.br
}

\begin{abstract}
A B S T R A C T
Artificial habitats have become common in coastal areas worldwide and may influence the structure and functioning of benthic ecosystems. We analyze the influence of piers on the benthic morphofunctional groups of rocky seaweeds and of soft bottom macrofauna in the channel of Conceição Lagoon (southern Brazil). The main impact is a reduction in the luminosity available for photosynthetic activity which is directly related to a decrease in the biomasses of sediment microphytobenthos and of more highly structured macroalgae life-forms. Contrary to expectations, the morphotypes of potentially high biomass productivity, such as articulated coralline, corticated and leathery macroalgae, were in general less abundant and the low biomass foliose and filamentous macroalgae occurred in reference areas but not under the piers. The piers' effects on motile epifauna and infauna functional groups were site-specific and probably related to the general reduction in primary producer organisms in the new habitats. The discretely motile infauna was the only functional group able to thrive under the piers due to their reduced motility and fragile morphological structures, being benefited by the shelter provided by the artificial habitats. Our results showed that the piers might have a negative effect on the base-trophic level organisms responsible for bottom-up controls.
\end{abstract}

\section{R E S UM O}

Hábitats artificiais têm se tornado comum em áreas costeiras no mundo todo, podendo influenciar a estrutura e funcionamento de ecossistemas bênticos. Nós analisamos a influência de trapiches nos grupos morfofuncionais bênticos de algas associadas a substrato consolidado e de macrofauna em substrato inconsolidado, no canal da Lagoa da Conceição (sul do Brasil). O principal impacto da presença de trapiches é a redução da irradiação disponível para atividade fotossintética, o que está diretamente relacionado com o decréscimo na biomassa microfitobentônica no sedimento e de macroalga de formas de vida mais complexas. Contrário ao esperado os morfotipos com alto potencial de produtividade de biomassa, como macroalgas calcárias articuladas, corticadas e coriáceas, em geral foram menos abundantes, sendo que macroalgas foliáceas e filamentosas de menor biomassa foram encontradas exclusivamente em áreas controle. Os efeitos do trapiche nos grupos funcionais de epifauna e infauna foram específicos ao ponto de coleta e provavelmente relacionados com redução generalizada de produtores primários e com o novo hábitat criado. A infauna discretamente móvel foi o único grupo funcional capaz de prosperar embaixo dos trapiches, devido à sua mobilidade reduzida e frágil estrutura morfológica, beneficiando-se do abrigo oferecido pelos hábitats artificiais. Nossos resultados mostraram que os trapiches podem ter um efeito negativo sobre os organismos da base da cadeia trófica, responsáveis pelo controle bottom-up.

Descriptors: Soft bottom, Rocky bottom, Macroalgae, Macrofauna, Functional analysis, Bottom-up control.

Descritores: Substrato consolidado, Substrato inconsolidado, Macroalga, Macrofauna, Grupos funcionais, Controle bottom-up. 


\section{INTRODUCTION}

Structural and functional analyses of benthic assemblages generally agree in their patterns of distribution irrespective of the trophic group investigated (PAGLIOSA, 2005; MAGALHÃES; BARROS, 2011). The redundancy in the number of species which describe a function (GRAY et al., 1988; CLARKE; WARWICK, 1998) and the number of functional groups present (HALPERN; FLOETER, 2008) are useful to indicate assemblage resilience to disturbances. However, the absence or the abundance of a specific functional group, formed by either primary producers or consumer-trophic species and exposed to similar disturbance levels, could bring insights on assemblage rules.

The unchecked human occupations of the marine landscapes are introducing new structures in coastal areas. Habitats are created that are different from those that are naturally occurring (GLASBY, 1999; ZINTZEN et al,. 2008; CALLIER et al., 2009; BULLERI; CHAPMAN, 2010). New habitats created by artificial structures such as piers, jetties and marinas can attract grazers and attenuate light, reducing fitness with species biomass losses and composition change in base-trophic level assemblages. Notwithstanding, the relationships between potential productivity of rocky bottoms macroalgae species and potential disturbance (in the sense of new created habitats) are not linear and may be better interpreted by mean of functional groups (ORFANIDIS et al. 2003; MURRAY et al., 2006). Macroalgae morphology and architecture match the potential productivity and general fitness of species (STENECK; DETHIER, 1994). Thus, one may expect morphofunctional groups of macroalgae with high biomass, i.e., articulated coralline, corticated and leathery algae to predominate in natural undisturbed habitats. In new artificial habitats which represent high disturbance, we could expect low biomass and a predominance of foliose, filamentous species, or even the absence of all macroalgae morphofunctional groups. Combining an intermediate productivity potential and species resilience to disturbances (light intensity, herbivory) the crustose algae functional group could figure an in-between stage (MURRAY et al., 2006).

Regarding the macrofauna, artificial habitats may alter dominant feeding strategies (WEISSBERGER et al., 2008), morphotype (PAGLIOSA, 2005) and motility (BREMNER et al., 2006; GAMITO; FURTADO; 2009) of soft sediments consumer-trophic level assemblages. In fact, the way to search for (motility), identify and take (morphology) food resources from the environment are so coupled that any other possible functional characteristics tend to be a secondary reflection of this interaction (FAUCHALD; JUMARS, 1979). Thus, the ability of an animal to move on or throughout the sediment will potentially be an important biological characteristic to cope with the new habitat provided by artificial structures. Motile species may actively choose suitable microhabitats, while discretely motile species may be more constrained in terms of habitat selection. Additional differences may arise from species characteristics and their ability to live either on or within sediments. Thus, epifaunal species must deal with environmental changes, predators, and a high degree of exposure, while infaunal species are generally sheltered within the sediments or inside protective tubes.

The macroalgal and macrofaunal benthic assemblages have been used historically as indicators of environmental quality, making them valuable tools for assessing potential changes within marine ecosystems (BORJA et al., 2010). Here, we used these two trophically distinct functional groups to assess the pressure from increased urbanization in coastal areas, specifically regarding piers structures. We addressed the following questions: does the presence of piers cause significant changes in the presence and abundance of macroalgae and macrofauna functional groups on rocky and soft sediment, respectively? If so, what morpho-functional and motility-functional groups are critical in dealing with those changes and are they related in some way?

\section{Material and Methods}

\section{Study area}

The study was conducted in the channel that links Conceição Lagoon to the Atlantic Ocean on the east coast of Santa Catarina Island in southern Brazil (Fig. 1). The channel is $3 \mathrm{~km}$ long and less than $5 \mathrm{~m}$ deep, with salinity and water temperature vertically homogeneous during flood or ebb tides, becoming partially mixed after major rainfall events. The tide regime is semidiurnal with diurnal inequalities and mean sea-level is $0.64 \mathrm{~m}$. Surface waves occurs with wind from the south or southeast.

The channel border is a mosaic of urbanized sites interspersed with stands of the grass Spartina alterniflora Loisel and Laguncularia racemosa Gaertn. The channel is mainly used by recreational and fishing boats, and comprises several buildings and piers along the margins. The channel harbors a total of 120 piers, most of them concentrated near the marine outfall. Seventy of them are placed on the northern side and fifty on the southern. The piers are built with PVC tubes filled up with concrete that support a wooden deck. Usually a few centimeters space is left in between the deck boards. 


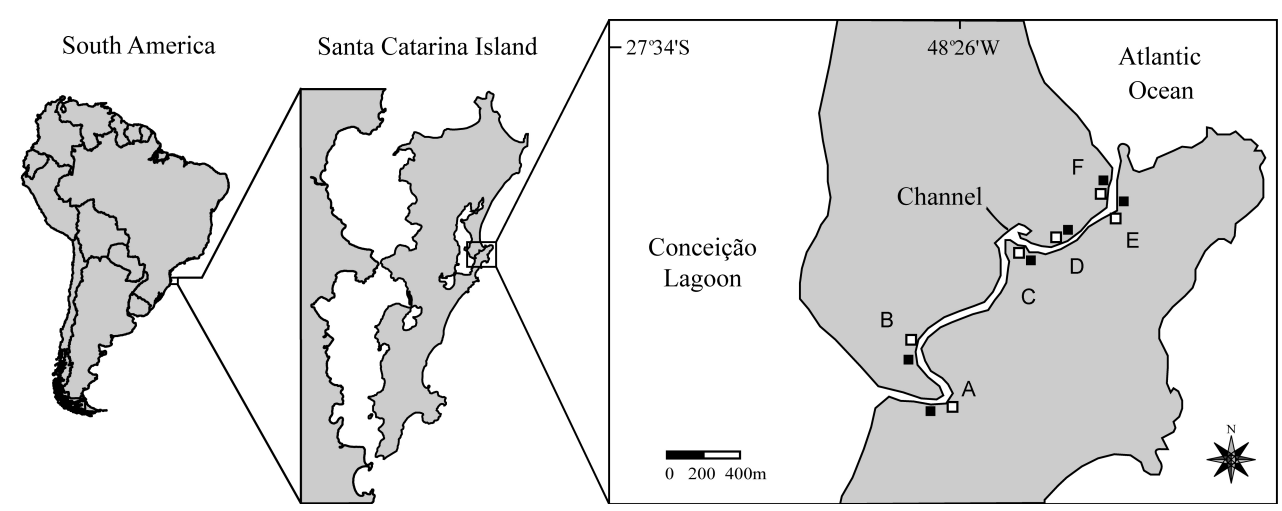

Fig. 1. The channel of Conceição Lagoon in southern Brazil showing piers areas (open squares) and reference areas (filled squares), in the six sampling sites (A, B, C, D, E and F).

Sampling Design and Sample Procedures

We surveyed benthic rocky and soft bottom assemblages in March 2009. Six pier sites along the channel were randomly chosen and coded from innermost (A) to outermost (F) sites (Fig. 1). All piers analyzed showed similar size and height in relation to the water surface. In each pier we sampled macroalgae on rocky substrate and macrofauna on soft bottoms under the piers. Rocky and soft bottoms, not covered by piers, were set as reference areas in the same border of the channel. For each pier was selected one reference area 10 to $50 \mathrm{~m}$ away to avoid edge effects. Reference rocky substrata were $9 \mathrm{~m}^{2}$ size at least and reference soft bottoms were on sand flat beside the first one. As the distances from consolidated structures may affect macrofaunal assemblage (BARROS et al., 2001) we maintained the same distances between rocky and soft substrata in reference sites as in pier sites. The substrate's integrity was also taken into account for the selection of reference areas.

Macroalgae were sampled from rocky substrata in all sites by scraping three 20 x $20 \mathrm{~cm}$ quadrats in each treatment. The samples were always taken from spots that had the same depth, inclination and position in relation to the sun. The species were preserved in $4 \%$ formalin made out with local water. For biomass estimates, samples were dried at $60^{\circ} \mathrm{C}$ for $48 \mathrm{~h}$ and then weighed $(0.0001 \mathrm{~g}$ - Bioprecisa FA2014 balance). The specimens were identified to the lowest reliable taxonomic level and subsequently categorized into five morphofunctional groups (Table 1): foliose, corticated, filamentous, leathery and articulated calcareous algae (STENECK; DETHIER, 1994; MURRAY et al., 2006).

Table 1. Functional groups of macroalgae and respective taxa. FO: Foliose, CO: Corticated, FI: Filamentous, LE: Leathery, and ACA: Articulated Calcareous.

\begin{tabular}{ll}
\hline \hline Taxa & Functional Group \\
\hline Rhodophyta & \\
Acanthophora spicifera (Vahl) Borgesen & CO \\
Acrochaetium sp. & FI \\
Centroceras clavulatum (Agardh) Montagne & FI \\
Ceramium comptum Borgesen & FI \\
Chondracanthus acicularis (Roth) Fredericq & CO \\
Chondracanthus teedei (Mertens ex Roth) Fredericq & CO \\
Erythrotrichia carnea (Dillwyn) Agardh & FI \\
Gelidium pusillum (Stackhouse) Le Jolis & CO \\
Gelidium crinale (Hare ex Turner) Gaillon & CO \\
Gymnogongrus sp. & CO \\
Hypnea spinella (Agardh) Kütz & FI \\
Polysiphonia subtilissima Montagne & FI \\
Geniculate Coralline & ACA \\
Heterokontophyta & \\
Bachelotia fulvescens (Bornet) Kuckuck ex Hamel & FI \\
Hincksia sp. (Silva) & FI \\
Feldmannia irregularis (Kütz) Hamel & FI \\
Sargassum cymosum Agardh & LE \\
Chlorophyta & \\
Chaetomorpha sp. & FI \\
Cladophora sp. & FI \\
Cladophoropsis membranacea (Hofman Bang ex Agardh) Borgesen & FI \\
Derbesia sp. & FI \\
Rhizoclonium riparium (Roth) Harvey & FI \\
Ulva chaetomorphoides (Borgesen) & FI \\
Ulva intestinalis (L.) Nees & FI \\
Ulva lactuca Linnaeus & FO \\
Cyanobacteria & \\
Oscillatorialles & FI \\
\hline
\end{tabular}


To check if piers could change sedimentation patterns we took three sediment samples of $200 \mathrm{~cm}^{3}, 5 \mathrm{~cm}$ deep. Sediment was dried $\left(60^{\circ} \mathrm{C}\right.$ for $48 \mathrm{~h}$ ) and used to determine the contents of organic matter $\left(550^{\circ} \mathrm{C}\right.$ for $\left.1 \mathrm{~h}\right)$, biodetritic carbonate $(\mathrm{HCl}$ $10 \%$ ), and sands by separation through a $63-\mu \mathrm{m}$ sieve (SUGUIO, 1973; DEAN, 1994). Additionally, as some faunal groups could forage on microphytobenthos, which may be affected by the piers, we collected three samples of $2 \mathrm{~cm}^{3}$ of top sediment with a half-cut syringe and measured the concentrations of chlorophyll $a$ and phaeophytin $a$ according to PlanteCuny (1978) methodology.

Macrofauna were sampled at all sites using three $10 \mathrm{~cm}$ diameter and $10 \mathrm{~cm}$ deep corers. Samples were washed through a $0.5-\mathrm{mm}$ mesh sieve and preserved in $10 \%$ formalin. All individuals were examined under the microscope, identified and counted. Subsequently, the organisms were classed as either living in or on the sediment, and their displacement potential (Table 2): motile epifauna, discretely motile epifauna, motile infauna and discretely motile infauna, was recorded (FAUCHALD; JUMARS, 1979; BREMNER et al., 2006).

Table 2. Functional groups of macrofauna and respective taxa. MI: Motile Infauna, DMI: Discretely Motile Infauna, ME: Motile Epifauna, and DME: Discretely Motile Epifauna.

\begin{tabular}{ll}
\hline \hline Taxa & $\begin{array}{c}\text { Functional } \\
\text { Group }\end{array}$ \\
\hline Polychaeta & \\
Alita succinea Frey and Leuckart & MI \\
Capitella sp. Fabricius & MI \\
Glycinde multidens Müller & MI \\
Laonice sp. & DMI \\
Magelona papillicornis Müller & DMI \\
Polydora sp. & DMI \\
Prionospio sp. & DMI \\
Scoletoma tetraura Schmarda & MI \\
Sigambra grubii Müller & MI \\
Syllidae & MI \\
Oligochaeta & DMI \\
Bivalvia & \\
Codakia costata Orbigny & DME \\
Anomalocardia brasiliana Gmelin & DMI \\
Brachidontes darwinianus Orbigny & DME \\
Lucina pectinata Gmelin & DMI \\
Tellina nitens Adams & DMI \\
Gastropoda & \\
Nassarius albus Say & DME \\
Cerithium atratum Born & DME \\
Littoridina australis Orbigny & DME \\
Amphipoda & \\
Monocorophium acherusicum Costa & ME \\
Cumacea & ME \\
Decapoda & ME \\
Nemertea & MEthozoa \\
Nematoda & DI \\
\hline & MI \\
\hline
\end{tabular}

To check on whether piers could change sedimentation patterns we took three sediment samples of $200 \mathrm{~cm}^{3}, 5 \mathrm{~cm}$ deep. Sediment was dried $\left(60^{\circ} \mathrm{C}\right.$ for $48 \mathrm{~h}$ ) and used to determine the organic matter content $\left(550^{\circ} \mathrm{C}\right.$ for $\left.1 \mathrm{~h}\right)$, biodetritic carbonate $(\mathrm{HCl} 10 \%)$, and coarseness of sand by separation through a $63-\mu \mathrm{m}$ sieve (SUGUIO, 1973; DEAN, 1994). Further, as some faunal groups could forage on microphytobenthos, which might be affected by the piers, we collected three samples of $2 \mathrm{~cm}^{3}$ of top sediment with a half-cut syringe and measured the concentrations of chlorophyll $a$ and phaeophytin $a$, in accordance with Plante-Cuny's (1978) methodology.

\section{Data Analysis}

Univariate analyses of piers effects were done on macroalgae and macrofauna functional groups abundance using two-way ANOVAs on sites (6 sites) and treatments (pier and reference areas). We used sites as random factor and treatments as fixed factor. One-way ANOVAs were applied testing each PAR values, and water and sediment variables between pier sites and reference sites. Student-Newman-Keuls (SNK) tests were used to evaluate significant differences among means. To reduce heterogeneity of variances all data were transformed as $\log (X+1)$. All analysis were run with $\mathrm{R} 2.12 .1$ software ( $\mathrm{R}$ DEVELOPMENT CORE TEAM 2010), using the GAD package (SANDRINI-NETO; CAMARGO, 2010).

\section{RESULT \\ Environmental Characteristics of Reference and Pier Areas}

Light reached the bottom of all sampling sites. However, photosynthetic irradiance was much higher in reference areas than under the piers (Table 3 ). Water and sediment parameters were nearly homogeneous in all areas. Salinity $(20.6 \pm 0.73 \mathrm{sd}, \mathrm{N}$ $=12)$ and temperature $\left(26 \pm 0.01^{\circ} \mathrm{C}\right.$ sd, $\left.\mathrm{N}=12\right)$ did not vary during sampling. The concentrations of dissolved nitrate, ammonia and phosphates, and suspended particulate matter were similar in reference areas and under the piers. Sediments were predominantly sandy with varying amounts of organic matter and biodetritic carbonate but did not differ significantly between the piers and reference areas. Although phaeophytin $a$ concentration in sediment were similar between treatments, chlorophyll $a$ content was higher in the reference areas. 
Table 3. Mean values $( \pm \mathrm{sd})$ for environmental variables in Reference $(\mathrm{R})$ and Pier $(\mathrm{P})$ areas in the channel of Conceição Lagoon, and F-ratio and significance levels of the one-way ANOVA testing effect of treatments. Differences between areas determined by Student Newman-Keuls (SNK) post hoc comparisons.

\begin{tabular}{|c|c|c|c|c|c|}
\hline \multirow[b]{2}{*}{ Environmental variables } & \multicolumn{2}{|c|}{ Area } & \multicolumn{2}{|c|}{ ANOVA } & \multirow[t]{2}{*}{ SNK } \\
\hline & $\begin{array}{l}\text { Reference } \\
(\mathbf{N}=6)\end{array}$ & $\begin{array}{l}\text { Pier } \\
(\mathrm{N}=6)\end{array}$ & $\mathbf{F}_{(1,5)}$ & $\mathbf{P}$ & \\
\hline $\begin{array}{l}\text { Photosynthetic activity irradiance }\left(\mu \mathrm{mol} \text { photon } \mathrm{m}^{-2} \mathrm{~s}^{-1}\right) \\
\text { Water variables }\end{array}$ & $2074 \pm 143.53$ & $18.27 \pm 17.97$ & 1211 & 0.001 & $\mathrm{R}>\mathrm{P}$ \\
\hline Phosphate $\left(\mu \mathrm{M} \mathrm{L}^{-1}\right)$ & $0.15 \pm 0.02$ & $0.14 \pm 0.02$ & 0.62 & 0.451 & ns \\
\hline Nitrate $\left(\mu \mathrm{M} \mathrm{L}^{-1}\right)$ & $2.13 \pm 0.39$ & $1.98 \pm 0.13$ & 0.75 & 0.408 & $\mathrm{~ns}$ \\
\hline Ammonia $\left(\mu \mathrm{M} \mathrm{L}^{-1}\right)$ & $0.64 \pm 0.12$ & $0.56 \pm 0.06$ & 22276 & 0.166 & $\mathrm{~ns}$ \\
\hline Suspended particulate matter $\left(\mathrm{mg} \mathrm{L}^{-1}\right)$ & $31.50 \pm 3.02$ & $31.37 \pm 2.36$ & 0.01 & 0.934 & ns \\
\hline Sediment variables & & & & & \\
\hline Chlorophyll $a\left(\mu \mathrm{g} \mathrm{cm}^{-2}\right)$ & $15.61 \pm 7.75$ & $4.59 \pm 1.35$ & 11782 & 0.006 & $\mathrm{R}>\mathrm{P}$ \\
\hline Phaeophytin $a\left(\mu \mathrm{g} \mathrm{cm}^{-2}\right)$ & $5.87 \pm 3.74$ & $11.35 \pm 14.08$ & 0.85 & 0.379 & ns \\
\hline Organic matter $(\%)$ & $2.28 \pm 1.41$ & $1.95 \pm 1.39$ & 0.17 & 0.690 & ns \\
\hline Fine $(\%)$ & $5.32 \pm 3.53$ & $4.79 \pm 3.91$ & 0.06 & 0.808 & ns \\
\hline Sandy $(\%)$ & $94.68 \pm 3.53$ & $95.21 \pm 3.91$ & 0.06 & 0.808 & $\mathrm{~ns}$ \\
\hline Biodetritic carbonate $(\%)$ & $4.05 \pm 3.40$ & $5.53 \pm 3.90$ & 0.49 & 0.498 & ns \\
\hline
\end{tabular}

\section{Benthic Functional Groups}

The trophically distinct benthic assemblages differed with the presence or the absence of piers. We recorded a total of 52 taxa in both rocky and soft bottom substrata. A total of 26 taxa of macroalgae were identified and grouped in five functional groups (Table 1). The foliose Ulva lactuca, the corticated Gymnogongrus sp. and Chondracanthus acicularis, plus the filamentous turf algae were the dominant taxa, representing more than $88.5 \%$ of the total biomass. Macroalgae were absent in ca. $60 \%$ of the piers (four out of the six sites). The corticated Chondracanthus acicularis and the leathery Sargassum cymosum were the only macroalgae that occurred under the piers.

A total of 26 taxa of macrofauna were identified and grouped in four functional groups (Table 2). The motile infauna Capitella sp., alita succinea and Sigambra grubii, the discretely motile infauna Polydora sp., Anomalocardia brasiliana and the unidentified Tubificidae, plus the motile epifauna Amphipods, accounted for more than $97 \%$ of the total density. The macrofauna functional groups responded differently to the pier effect (Fig. 3). The densities of discretely motile infauna were higher under the piers than in the reference areas and were higher at only one of the sampled sites. The densities of motile infauna and motile epifauna differed between treatments depending on the site observed. Motile epifauna densities were higher under the piers than in the reference areas only at one of the channel's inner sites. Motile infauna showed alternate responses (higher/lower densities or no significance) between treatments. The density of discretely motile epifauna did not differ between treatments and sites

Biomasses of filamentous and foliose macroalgae were significantly lower below the piers. Since articulated calcareous and leathery algae biomasses were low, they did not differ between the treatments (Fig. 2). Corticated macroalgae biomass varied between treatments depending on the site analyzed, being higher in reference areas located in the outer sites of the lagoon channel.

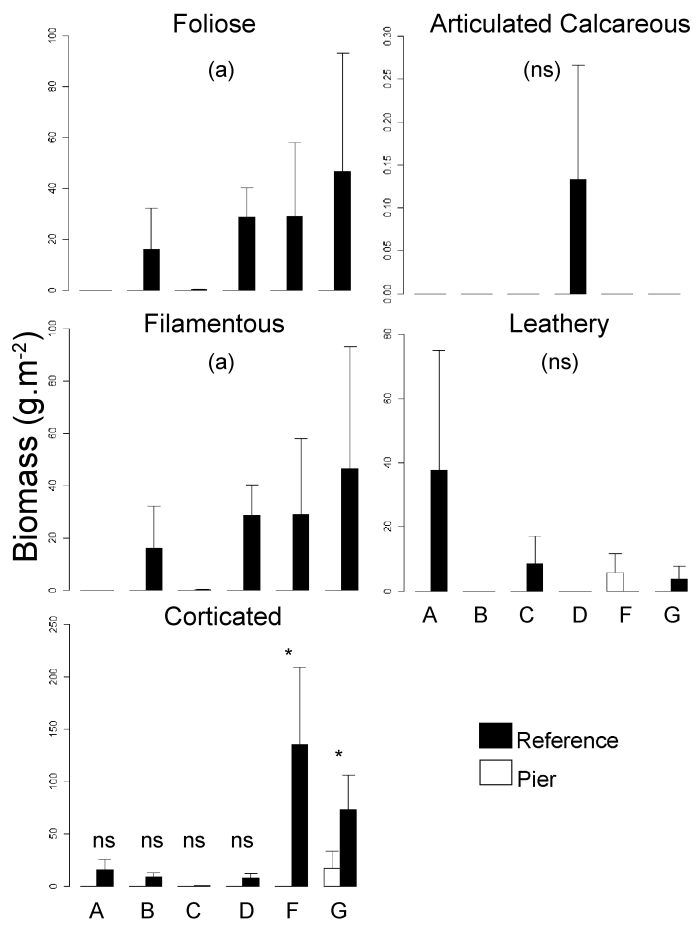

Fig. 2. Mean values $( \pm \mathrm{SE})$ of macroalgae functional groups biomass in piers areas (open bars) and in reference areas (filled bars) in the six sites (A, B, C, D, E and F). (ns) Designates not significant differences and (a) and (s) significant differences between areas or sites, respectively, at $\mathrm{P}<0.05$ by ANOVA. $*$ and ns designates significant and not significant differences at $\mathrm{P}<0.05$ by SNK test. 

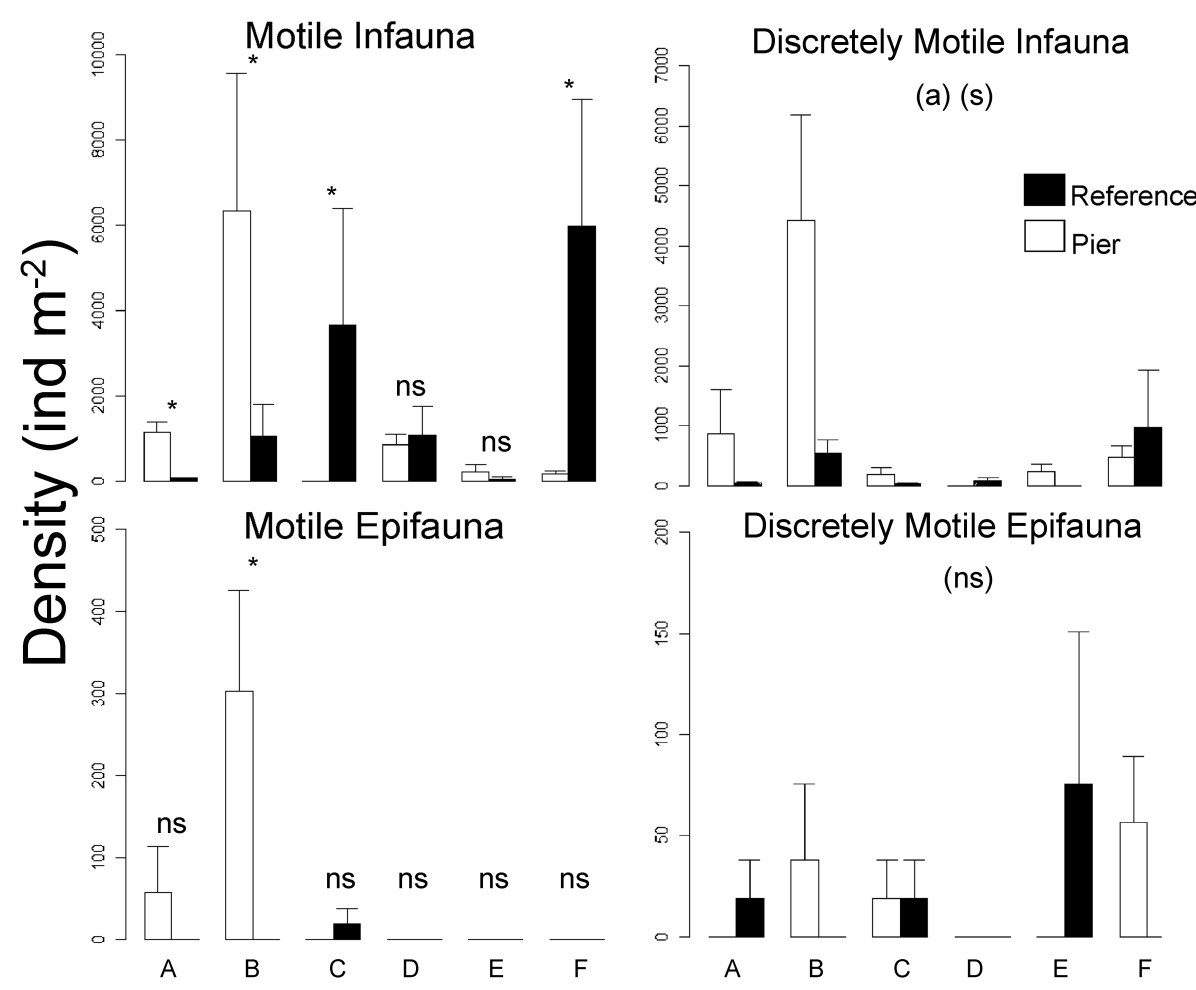

Fig. 3. Mean values $( \pm \mathrm{SE})$ of macrofauna functional groups density in piers areas (open bars) and in reference areas (filled bars) in the six sites (A, B, C, D, E and F). (ns) Designates not significant differences and (a) and (s) significant differences between areas or sites, respectively, at $\mathrm{P}<0.05$ by ANOVA. * and ns designates significant and not significant differences at $\mathrm{P}<0.05$ by SNK test.

\section{Discussion}

Despite the uniformity of most of the physical and chemical parameters measured in the studied area we detected differences in the biota under the piers. The differences must be credited to the reduction in the amount of PAR irradiance that reaches the bottom once the local piers act mainly as a physical barrier to light, significantly reducing irradiance available for photosynthetic activity. The shading caused by piers decreased phytobenthic biomass what is also evidenced by the reduction of chlorophyll $a$. It also precluded the presence of filamentous, foliose and articulated calcareous algae. However, despite functional groups (macrophytes) usually respond meaningfully to the light exposure (MARKAGER; SAND-JENSEN, 1994), our findings showed no specific relation in this aspect.

The reduction of structurally more complex marine primary producers under reduced irradiation has already been demonstrated for seagrasses (ENRIQUEZ; PANTOJA-REYES, 2005) and seaweeds (STENECK; DETHIER, 1994). For macroalgae functional groups these mean values varies from 0.50 and $0.93 \mu \mathrm{mol}$ photons $\mathrm{m}^{-2} \mathrm{~d}^{-1}$ in leathery and corticated groups, respectively, to $0.13 \mu \mathrm{mol}$ photons $\mathrm{m}^{-2} \mathrm{~d}^{-1} 1$ in foliose taxa, and to $1.4 \mu \mathrm{mol}$ photons $\mathrm{m}^{-2} \mathrm{~d}^{-1}$ in filamentous species (GATTUSO et al., 2006). Considering that our sampling was carried out during the summer, in a sunny day, the observed values could be considered as potentially maximums. Then the mean irradiance under the pier structure varied around $0.75 \mu \mathrm{mol}$ photons $\mathrm{m}^{-2} \mathrm{~d}^{-1}$, sufficient to support leathery algae but insufficient to other groups as previously described by Gattuso et al. (2006). Reinforcing this idea, germlings of some species of Sargassum, among other leathery taxa, can thrive under irradiation levels similar to the ones we measured under the piers studied (THIBAUT et al., 2005; CHOI et al., 2008).

On the other hand, we observed that macroalgae biomass resulted from gross primary production balances, highlighting the potential carbon losses (respiration, senescence, thallus necrosis/losses, herbivory, exudation of dissolved organic carbon, and reproduction) for each functional group. Thus the absence or abundance reduction of all functional groups under the pier must represent that the 
compensation irradiance for effective growth (MARKAGER; SAND-JENSEN, 1994) was not available. In addition, the obvious irradiance reduction in the winter, due the day length and available PAR reduction, may represent an additional factor that could contributing to the annual leathery and corticated groups reduction/exclusion (i.e., they could not colonize the habitat under the pier during the cold season).

The hypothesized fine relationship between macroalgae morphology and the potential productivity and general fitness of species can be observed partially. Despite of the presence and eventual dominance of corticated groups, the relative high abundance of low productive foliose and filamentous algae in the reference area maybe a result of the urban runoff plus sewage of 15.000 inhabitants that live in the lagoon margin. This scenario can be inferred by the high dissolved nitrogen concentration in all the studied area (FONSECA, 2006; FONSECA; BRAGA, 2006). The overall decline of the traditionally dominant groups such as leathery in the southwestern Atlantic coast has been already evidenced and could be related to the general environmental impoverishment (HORTA et al., 2008).

Besides the reduction of macroalgae biomass, piers also restrict the presence of Spartina alterniflora and Laguncularia racemosa along channel borders. Therefore, the construction of piers could significantly change the function of a coastal ecosystem simply by removing or reducing basetrophic level organisms. Considering a cascade effect (NEWCOMBE; TAYLOR, 2010), this could disrupt the bottom-up control, with consequences to herbivores and detritivorous organisms. As piers have a potential to work as attractors to herbivorous fish (RILOV; BENAYAHU, 2000; BULLERI; CHAPMAN, 2010), this can add up to light reduction to explain the decrease in the abundance of macroalgae functional groups. As an indirect effect of environmental heterogeneity loss the benthic infauna and epifauna could also be evading to new suitable habitats. At the inner sites, with less macroalgae types, the fauna occupied the piers habitat. On the other hand, at the outer sites, where the environment was more dynamic and the algae biomass was more expressive, the fauna, mainly the motile infauna, preferred the reference areas.

In fact, epifaunal group are able to search for ephemeral high food quality patches (KIHSLINGER; WOODIN, 2000), either by actively moving from place to place (e.g., motile epifauna), or by finding a suitable habitat for patch life (e.g., discretely motile epifauna). In the same way, motile infauna probably moves between natural and created habitats, feeding on sunken accumulated resources or seeking prey. Thus, the responses of above macrofauna motility- functional groups to the pier effect greatly varied and were site-specific. Furthermore, these faunal groups seem to be subjected more to other environmental constrains (i.e., general reduction in food supply) rather than being influenced by the piers.

Contrariwise, the discretely motile infauna functional group could migrate from the destroyed salt marsh to the modified habitat. Manipulative experiments showed that species of discretely motile infauna functional group, such as Lucina pectinata and Polydora sp., are associated with $S$. alterniflora (PAGLIOSA; LANA, 2000, 2005). The presence of surface and subsurface plant structures greatly influences the density of infaunal species because these structures provide food, refuge, and physical support to the organisms' tubes (LANA; GUISS, 1992). In this sense, discretely motile infauna functional group could be dealing with new artificial habitats mainly because of their lower motility coupled with gain in protection. The discretely motile faunal group was made by individuals with very fragile structures to live and feed mainly. They are strictly filter feeders, such as the bivalves Lucina pectinata, Tellina nitens, and Anomalocardia brasiliana, or detritus-filter feeders, such as the spionids polychaetes Laonice, Polydora, and Prionospio. Filter feeders species use gills and detritus-filter feeder species use palps to feed, and all of them need to inhabit a suitable place to live because they cannot quickly escape or avoid predators without damaging their feeding structures.

The analysis of piers influence in the Conceição lagoon channel on benthic primary producers and consumers functional groups showed distinct but interrelated responses. The macroalgae responded to lower irradiance levels available for photosynthetic activity, while macrofauna was mostly influenced by patchy or site-specific resources. The general environmental depletion highlights the coupled responses observed for the benthic algae and fauna. We can conclude that, all algal functional groups responded negatively to the abiotic and biotic conditions provided by the piers. Regarding the macrofauna the primary production reduction and the presence of the new habitats resulted in changes of the analyzed groups. Thus, we concluded that piers exert a negative effect over base-trophic level organisms responsible for bottom-up controls.

\section{ACKNOWLEDGEMENTS}

We would like to thank F.L. Lobato, C. Sutil, F.V.R. Almeida, M.B. Batista, T.V. Pinto, S. Dutra, M.C. Moreira, and D.R. Barneche for aiding this project. We are grateful to E. Oliveira and A.S. Rovai for valuable comments on the manuscript. The 
authors were supported by the Brazilian Research Council (CNPq and CAPES).

\section{REFERENCES}

BARROS, F.; UNDERWOOD, A. J.; LINDEGARTH, M. The Influence of Rocky Reefs on Structure of Benthic Macrofauna in Nearby Soft-sediments. Estuar. Coast. Shelf Sci., v. 52, p. 191-199, 2001.

BORJA, A.; DAUER, D. M.; ELLIOTT, M.; SIMENSTAD, C. A. Medium- and long-term recovery of estuarine and coastal ecosystems: patterns, rates and restoration effectiveness. Estuar. Coasts, v. 33, p. 1249-1260, 2010.

BREMNER, J.; ROGERS, S. I.; FRID, C. L. J. Methods for describing ecological functioning of marine benthic assemblages using biological traits analysis BTA. Ecol. Indic., v. 6, p. 609-622, 2006.

BULLERI, F.; CHAPMAN M. G. The introduction of coastal infrastructure as a driver of change in marine environments. J. Appl. Ecol., v. 47, p. 26-35, 2010.

CALLIER, M. D.; FLETCHER, R. L.; THORP, C. H.; FICHET, D. Macrofaunal community responses to marina-related pollution on the south coast of England and west coast of France. J. Mar. Biol. Assoc. UK, v. 89, p. 19-29, 2009.

CHOI, H. G.; LEE, K. H.; YOO, H. I.; KANG, P. J.; KIM, Y. S.; NAM, K.W. Physiological differences in the growth of Sargassum horneri between the germling and adult stages. J. Appl. Phycol., v. 20, p. 729-735, 2008.

CLARKE, K. R.; WARWICK, R. M. Quantifying structural redundancy in ecological communities. Oecologia, v. 113 , p. 278-289, 1998.

DEAN, W. E. Determination of carbonate and organic matter in calcareous sediments and sedimentary rocks by loss on ignition: comparison with other methods. J. Sediment. Petrol., v. 44, p. 242-248, 1994.

ENRÍQUEZ, S.; PANTOJA-REYES, N. I. Form-function analysis of the effect of canopy morphology on leaf selfshading in the seagrass Thalassia testudinum. Oecologia, v. 145, p. 235-243, 2005.

FAUCHALD, K.; JUMARS, P. A. The diet of worms: a study of polychaete feeding guilds. Oceanogr. Mar. Biol. Annu. Rev., v. 17, p. 193-284, 1979.

FONSECA, A. Efeito da drenagem urbana nas características físico-químicas e biológicas da água superficial da lagoa da Conceição. Biotemas, v. 19, p. 7-16, 2006.

FONSECA, A.; BRAGA, E. S. Temporal dynamic of the dissolved nutrients and the eutrophization processes in a southern Brazilian coastal lagoon, Conceição Lagoon. J. Coast. Res., v. 39, p. 1229-1233, 2006.

GAMITO, S.; FURTADO, R. Feeding diversity in macroinvertebrate communities: A contribution to estimate the ecological status in shallow waters. Ecol. Indic., v. 9, p. 1009-1019, 2009.

GATTUSO, J. P.; GENTILI, B.; DUARTE, C. M.; KLEYPAS, J. A.; MIDDELBURG, J. J.; ANTOINE, D. Light availability in the coastal ocean: impact on the distribution of benthic photosynthetic organisms and their contribution to primary production. Biogeosci., v. 3, p. 489-513, 2006.

GLASBY, T. M. Differences between subtidal epibiota on pier pilings and rocky reefs at marinas in Sydney,
Australia. Estuar. Coast. Shelf Sci., v. 48, p. 281-290, 1999.

GRASSHOFF, K.; EHRHARDT, M.; KREMLING, K. Methods of seawater analysis. Weinheim: Verlag Chemie, 1983. $632 \mathrm{p}$.

GRAY; J. S.; ASCHAN, M.; CARR, M. R.; CLARKE, K. R.; GREEN, R. H.; PEARSON, T. H.; ROSENBERG, R.; WARWICK, R. M. Analysis of community attributes of the benthic macrofauna of Frierfjord/Langesund-fjord and in a mesocosm experiment. Mar. Ecol. Prog. Ser., v. 66, p. 285-299, 1988.

HALPERN, B. S.; FLOETER, S. R. Functional diversity responses to changing species richness in reef fish communities. Mar. Ecol. Prog. Ser., v. 364, p. 147-156, 2008.

HORTA, P. A.; SALLES, J. P.; BOUZON, J.; SCHERNER, F.; CABRAL, D.; BOUZON, Z. L.; ZANETTI, G.; ALENCAR, J. R. Composição e estrutura do fitobentos do infralitoral da reserva biológica marinha do Arvoredo, Santa Catarina, Brasil: implicações para a conservação. Oecologia Bras., v. 12, p. 51-57, 2008.

KIHSLINGER, R. L.; WOODIN, S. A. Food patches and a surface deposit feeding spionid polychaete. Mar. Ecol. Prog. Ser, v. 201, p. 233-239, 2000.

LANA, P. C.; GUISS, C. Macrofauna-plant biomass interactions in a euhaline salt marsh in Paranagua Bay SE Brazil. Mar. Ecol. Prog. Ser., v. 80, p. 57-64, 1992.

MAGALHÃES, W.; BARROS, F. Structural and functional approaches to describe polychaete assemblages: ecological implications for estuarine ecosystems. Mar. Freshw. Res., v. 62, p. 918-926, 2011.

MARKAGER, S.; SAND-JENSEN, K. The physiology and ecology of light-growth relationship in macroalgae. Prog. Phycol. Res., v. 10, p. 209-298, 1994.

MURRAY, S. N.; AMBROSE, R. F.; DETHIER, M. N. Monitoring rocky shores. Berkeley: University of California Press, 2006. 220 p.

NEWCOMBE, E. M.; TAYLOR, R. B. Trophic cascade in a seaweed-epi-fauna-fish food chain. Mar. Ecol. Prog. Ser., v. 408, p. 161-167, 2010.

ORFANIDIS, S.; PANAYOTIDIS, P.; STAMATIS, N. An insight to the ecological evaluation index EEI. Ecol. Indic., v. 3, p. 27-33, 2003.

PAGLIOSA, P. R. Another diet of worms: the applicability of polychaete feeding guilds as a useful conceptual framework and biological variable. Mar. Ecol., v. 26, p. 246-254, 2005.

PAGLIOSA, P. R.; LANA, P. C. Populational dynamics and secondary production of Nereis oligohalina Nereididae: Polychaeta from a subtropical marsh in SE Brazil. Bull. Mar. Sci., v. 67, p. 259-268, 2000.

PAGLIOSA, P. R.; LANA, P. C. Impact of plant cover removal on macrobenthic community structure of a subtropical salt marsh. Bull. Mar. Sci., v. 77, p. 1-17, 2005.

PLANTE-CUNY, M. R. Pigments photosynthetiques et production primaire des fonds meubles meritiques d'une region tropicale Nosy-Be, Madagascar. Trav. Doc. ORSTOM, v. 96, p. 1-359, 1978.

$\mathrm{R}$ DEVELOPMENT CORE TEAM. R: A language and environment for statistical computing. $R$ Foundation for Statistical Computing, Vienna, Austria. ISBN 3900051-07-0. http://www.R-project.org. Accessed 2 May 2011. 
RILOV, G.; BENAYAHU, Y. Fish assemblage on natural vs. vertical artificial reefs in Eilat Red Sea: the rehabilitation perspective. Mar. Biol., v. 136, p. 931-942, 2000.

SANDRINI-NETO, L.; CAMARGO, M. G. GAD: an R package for ANOVA designs from general principles. 2010. http://cran.r-project.org/web/packages/GAD. Accessed 2 May 2011

STENECK, R. S.; DETHIER, M. N. A functional group approach to the structure of algal-dominated communities. Oikos, v. 69, p. 476-498, 1994.

STRICKLAND, J. D. H.; PARSON, T. A practical handbook of seawater analysis. Ottawa: Fish Res, 1972, 310 p.

SUGUIO, K. Introdução à sedimentologia. São Paulo: Edgar Blücher, 318 p. 1973.

THIBAULT, T.; PINEDO, S.; TORRAS, X.; BALLESTEROS, E. Long term decline of the populations of Fucales Cystoseira spp. and Sargassum spp. in the Albères coast France, North-western Mediterranean. Mar. Pollut. Bull., v. 50, p. 1472-1489, 2005 .
WEISSBERGER, E. J.; JUMARS, P. A.; MAYER, L. M.; SCHICK, L. L. Structure of a northwest Atlantic Shelf macrofaunal assemblage with respect to seasonal variation in sediment nutritional quality. J. Sea Res., v. 60, p. 164-175, 2008.

ZINTZEN, V.; NORRO, A.; MASSIN, C.; MALLEFET, J. Spatial variability of epifaunal communities from artificial habitat: Shipwrecks in the Southern Bight of the North Sea. Estuar. Coast. Shelf Sci., v. 76, p. 327-344, 2008 .

(Manuscript received 06 July 2011; revised 4 October 2011; accepted 3 March 2012) 